\title{
Grammar in parsing and acquisition
}

Chondrogianni, V.; Tamburelli, M.

\section{Linguistic Approaches to Bilingualism}

DOI:

10.1075/lab.3.3.03cho

Published: 01/01/2013

Peer reviewed version

Cyswllt i'r cyhoeddiad / Link to publication

Dyfyniad o'r fersiwn a gyhoeddwyd / Citation for published version (APA):

Chondrogianni, V., \& Tamburelli, M. (2013). Grammar in parsing and acquisition. Linguistic Approaches to Bilingualism, 3(3), 289-295. https://doi.org/10.1075/lab.3.3.03cho

\footnotetext{
Hawliau Cyffredinol / General rights

Copyright and moral rights for the publications made accessible in the public portal are retained by the authors and/or other copyright owners and it is a condition of accessing publications that users recognise and abide by the legal requirements associated with these rights.

- Users may download and print one copy of any publication from the public portal for the purpose of private study or research.

- You may not further distribute the material or use it for any profit-making activity or commercial gain

- You may freely distribute the URL identifying the publication in the public portal ?
}

Take down policy

If you believe that this document breaches copyright please contact us providing details, and we will remove access to the work immediately and investigate your claim. 


\section{Linguistic Approaches to Bilingualism \\ Grammar in parsing and acquisition --Manuscript Draft--}

\begin{tabular}{|l|l|}
\hline Manuscript Number: & LAB-D-12-00041R1 \\
\hline Full Title: & Grammar in parsing and acquisition \\
\hline Short Title: & \\
\hline Article Type: & Squib/Short article \\
\hline First Author: & Vasiliki Chondrogianni \\
\hline Other Authors: & Marco Tamburelli \\
\hline Corresponding Author: & $\begin{array}{l}\text { Vasiliki Chondrogianni } \\
\text { Bangor Unviersity }\end{array}$ \\
\hline Section/Category: & Bangor, Gwynedd UNITED KINGDOM \\
\hline Keywords: & Basic Science Section \\
\hline Abstract: & \\
\hline Author Comments: & \\
\hline Order of Authors Secondary Information: & \\
\hline
\end{tabular}




\section{Grammar in parsing and acquisition}

\section{A processor without grammar?}

O'Grady suggests that children map sequences onto "semantic representation" without "making reference to conventional syntactic representations" (p. 4). This represents a "strong" version of Emergentism, as it does not simply claim that language acquisition occurs in the absence of pre-existent linguistic knowledge or UG; it claims that acquiring language involves acquiring no linguistic knowledge at all. It maintains, somewhat paradoxically, that a system can learn to process structural relationships without developing any knowledge about "structure" or "relationships". O'Grady's proposal appears not to satisfy its requirements, however, as the supposedly "grammar-free" process is associated with many a grammatical concept, not least that of hierarchical relations. 
To begin with, O'Grady proposes that the processor develops a "routine" for

\footnotetext{
${ }^{1}$ All tree structures represent hierarchical relationships but not all hierarchical relationships are represented by tree structures.
}

A major issue here is that $\langle a\rangle$ and $\langle\mathrm{b}\rangle$ relate to the predicate in non-equivalent ways, as evident in the fact that they look suspiciously like an ordered pair, a well-known notational alternative to tree structure. In view of this, O’Grady appears to achieve one of two things: (i) relocating syntactic principles into what he calls "semantic representation"; (ii) providing a notational variant of syntactic relations. In the first case, O'Grady's proposal would be plausible, though not new (Jackendoff, 2007; Lamb, 1966), while the second case would merely be a notational exercise. Syntactic relations are hardly abandoned, however. They are either embedded into semantics or recast through different notational conventions.

Hierarchical relations resurface when O'Grady introduces routines for interpreting the form NP-V-NP, a combination of grammatical entities, by definition. Abandoning the term "grammar" and simply calling these objects "hierarchical" would of course affect only terminology rather than the underlying issue, namely that language processing involves structural relations beyond individual words. It seems therefore clear that the processor cannot "subsume the duties of the grammar" (p. 8), or dispense with "grammatical rules and principles" (p. 3), at least to the extent that these are patterns of hierarchical relationships.

Notably, hierarchical relations are neither exclusive to UG nor equivalent to tree structures, ${ }^{1}$ an issue that is not always explicit in O'Grady's exposition. Hierarchy can be successfully represented through dependency relations (J. Anderson, 1971; Hudson, 1984), 
strata (Lamb, 1966), or any mechanism that handles non-linear relationships, which is ultimately what grammar is.

O'Grady does argue convincingly that the processor and the grammar need not be separate, though this idea has been previously formulated (Phillips, 1996). Nevertheless, showing that a processor can subsume some of the duties associated with UG is not equivalent to showing that we can discard grammar altogether, nor that language acquisition occurs without "construction [...] of linguistic knowledge" (p. 2).

Indeed, O'Grady overtly contradicts this latter claim by borrowing Hawkins' (2004) suggestion that universals arise from a working memory requirement to "minimize the distance between the verb and [...] its dependent phrases" (p. 8). Crucially, for this explanation to work it is essential to credit the processor (or working memory) with knowledge of concepts such as "head", "selection", and "phrase", all run-of-the-mill grammatical notions. This is clear from O'Grady's examples, where the dispreferred option involves the intervention of a phrase (a syntactic constituent), and not of linear material, as a grammar-free working memory account would expect. Dispreferring “* * read that are highly regarded books" does not entail dispreferring the equally long but structurally different "read fairly highly regarded academic books". It is specifically structural interference, not linear length, that creates the working memory problem. Therefore, the explanation O'Grady embraces makes explicit reference to "conventional syntactic representations" (cf. p. 4). The phenomena that cannot be explained linearly are many, including V2, auxiliary inversion, island effects, etc.

It is therefore clear that even an initial description of a processing-based account must call upon relationships that fall entirely within the domain of grammar, whatever label we wish to use (e.g. structural/hierarchical/dependency), contrary to the claim that developmental events do not require "reference to conventional grammatical rules or 
representations" (p. 9). While the Amelioration Hypothesis might reduce the number of

\section{Acquisition and processing of scope}

To test his predictions regarding linear parsing and routine efficiency, O'Grady examines a poverty-of-the-stimulus phenomenon, namely scope relations between negation markers and quantifiers. The quantifier-negation interactions are subject to cross-linguistic variation and, according to O'Grady, their acquisition should mirror dominant target language processing routines. However, cross-linguistic findings show that relative linear order does not predict scope preferences (Szabolcsi, 2002). Acquisition studies from Korean and Japanese further contradict a linear analysis. Both languages have an SOV word order whereby the quantifier precedes negation $(\forall>$ not). Korean-speaking children have been shown to prefer this linear interpretation (Lee, Kwak, Lee, \& O'Grady, 2011), whereas Japanese-speaking children opt for the narrow scope interpretation (not $>\forall$ ), against the linear surface order (Goro \& Akiba, 2004).

Evidence that children parse quantifier-negation interactions on the basis of structural relations rather than linearly comes from studies with Kannada-speaking children (Lidz \& Musolino, 2002). Kannada, like Korean, is an SOV language where quantified objects are c-commanded by negation but are not linearly preceded by it. In a sentence such as Cookie Monster didn't eat two slices of pizza, Kannada-speaking children followed the syntactic (c-command) structure rather than the surface order, thus behaving like Englishspeaking children. This finding is not in line with the results from Korean-speaking children 
reported by O'Grady, who unambiguously prefer the wide scope interpretation. As O'Grady notes, the results from Kannada-speaking children do not necessarily contradict his predictions, as the types of quantifiers in the two studies differed. A numeral is always interpreted within the scope of negation, whereas a universal quantifier is always ambiguous between the two interpretations. However, this distinction suggests that children are sensitive to the interpretation of quantified NPs as a function of the lexical nature of the quantifiers and of their syntactic position (Musolino \& Gualmini, 2011). This sensitivity presupposes grammatical knowledge that exceeds linearity. Furthermore, postulating that each scopal pattern requires separate routines is against a notion of processing efficiency.

Routine efficiency also seems to be subject to experimental manipulations. Experimental studies have shown that adult speakers of English fail to access the felicitous interpretation, when experimental conditions are manipulated (Conroy, 2008; Musolino \& Lidz, 2003). These findings challenge O'Grady's argument regarding preferred routines. If preferred routines were in place, then we would not expect adults to opt for the non-felicitous interpretation against the dominant routine.

O'Grady makes the thought-provoking claim that parsing involves unidirectionality and processing cost. "Unidirectionality" claims that interpreting an item as soon as it is encountered enhances ease of processing. However, this assumption is problematic in relation to well-known garden path (GP) sentences, such as "Without her contributions would be impossible". If the processor interpreted "her" immediately upon encountering it, it would build the perfectly plausible unit [without her], then discard "her" from working memory and proceed to the next unit without being garden-pathed. Contrary to the Unidirectionality claim, however, such sentences show that the processor prefers a "wait and see" strategy (Frazier \& Rayner, 1982), favouring the sequence [without her contributions] instead of the equally plausible but more incremental [without her]. 
By assigning scope-induced cost to the processor, O'Grady captures certain welldocumented generalisations regarding surface scope. For example, non-linear scopal interpretations are seen as computationally more costly in theoretical models of scope (Fox, 2000; Musolino \& Gualmini, 2011; Reinhart, 2006). Psycholinguistic experiments have also reported that inverse-scope configurations are dispreferred because they are computationally more costly (C. Anderson, 2004). Processing studies have shown that children have difficulties revising initial parsing interpretations (Snedeker, 2009; Trueswell, Sekerina, Hill, \& Logrip, 1999). In his paper, O’Grady seems to conflate off-line accuracy on a truth-value judgment task, a metalinguistic and cognitively demanding task, with processing cost, which is more reliably measured using on-line methodologies that tap into sentence comprehension in real-time (Marinis, 2010; Sekerina, Fernández, \& Clahsen, 2008). Nevertheless, his predictions regarding processing cost are potentially testable by applying more fine-grained on-line methodologies. The extent to which it is possible to tease apart O'Grady's predictions from those of grammar-based accounts that evoke processing cost (C. Anderson, 2004), is in need of further investigation.

Turning to L2 acquisition, O'Grady's Transfer Calculus argues that L2 learners will transfer dominant processing routines from the L1, unless the cost of implementing the L1 routine in the L2 is high. Recent bidirectional studies by Grüter et al. (2010) investigating scope ambiguities in the context of disjunction and negation in speakers of L2 English and Japanese provide more data to test O'Grady's predictions. Grüter et al. (2010) examined the acquisition of scope and disjunction in Japanese L2 learners of English and English L2 learners of Japanese. According to O'Grady's parsing model, the dominant routine in English would be the one where negation takes scope over disjunction, as dictated by the linear order $(\neg>V)$. In Japanese the dominant routine is the exact opposite, since disjunction linearly precedes negation $(V>\neg)$. Therefore, for English learners of L2 Japanese and Japanese 
learners of L2 English transferring the L1 interpretations on to the L2 would involve costly operations, as this would involve interpreting an operator (i.e. negation or disjunction) before it is encountered. O'Grady's transfer calculus would thus predict that L1 transfer would be blocked in the case of Japanese learners of L2 English and English learners of L2 Japanese. Results from Grüter et al. (2010) seem to go against O'Grady's predictions. In their study, Grüter et al. (2010) showed that both Japanese learners of L2 English and English learners of Japanese initially transferred the L1 settings on to the L2. These results seem to be compatible with the predictions made by the Full Transfer/Full Access model of L2 acquisition (Schwartz \& Sprouse, 1994) combined with a Semantic Subset Principle (Crain, Ni, \& Conway, 1994).

Overall, O'Grady's article raises a number of challenging yet recurring issues in first and second language acquisition and processing by making testable predictions that future research will benefit from exploring further. Nevertheless, a full account is likely to need a stronger involvement of at least some grammatical relations that go beyond linear considerations.

Authors' addresses

Vasiliki Chondrogianni

School of Linguistics and English Language

Bangor University

New Arts building

Bangor LL57 2DG

v.chondrogianni@bangor.ac.uk
Marco Tamburelli

School of Linguistics and English Language

Bangor University

New Arts building

Bangor LL57 2DG

m.tamburelli@bangor.ac.uk 


\section{References}

Anderson, C. (2004). The structure and real-time comprehension of quantifier scope ambiguity. Unpublished $\mathrm{PhD}$ dissertation, Northwestern University.

Anderson, J. (1971). The grammar of case: Towards a localistic theory. Cambridge: Cambridge University Press.

Chomsky, N. (1993). A minimalist program for linguistic theory. In K. Hale, \& S. J. Keyser (Eds.), The view from building 20 (pp. 1-52). Cambridge, MA: MIT Press.

Conroy, A. (2008). The role of verification strategies in semantic ambiguity resolution in children and adults. Unpublished PhD dissertation, University of Maryland.

Crain, S., Ni, W., \& Conway, L. (1994). Learning, parsing, and modularity. In C. Clifton, L. Frazier \& K. Rayner (Eds.), Perspectives on sentence processing (pp. 443-467). Hillsdale, NJ: Erlbaum.

Fox, D. (2000). Economy and semantic interpretation. Cambridge, MA: MIT Press.

Frazier, L., \& Rayner, K. (1982). Making and correcting errors during sentence comprehension: Eye movements in the analysis of structurally ambiguous sentences. Cognitive Psychology, 14, 178-210.

Gibson, E. A., \& Pearlmutter, N. J. (Eds.). (2011). The processing and acquisition of reference. Cambridge, MA: MIT Press.

Goro, T., \& Akiba, S. (2004). Japanese disjunction and the acquisition of positive polarity. In Y. Otsu (Ed.), Proceedings of the fifth Tokyo conference on psycholinguistics (pp. 137162). Tokyo: Hituzi Syobo. 
Grüter, T., Lieberman, M., \& Gualmini, A. (2010). Acquiring the scope of disjunction and negation in L2: A bidirectional study of learners of Japanese and English. Language Acquisition, 17, 127-154.

Gualmini, A., \& Crain, S. (2005). The structure of children's linguistic knowledge. Linguistic Inquiry, 36, 463-474.

Hawkins, J. A. (2004). Efficiency and complexity in grammars. Oxford: Oxford University Press.

Hudson, R. (1984). Word grammar. Oxford: Blackwell.

Jackendoff, R. (2007). Language, consciousness, culture: Essays on mental structure. Cambridge, MA: MIT Press.

Lamb, S. M. (1966). Outline of stratificational grammar. Washington, DC: Georgetown University Press.

Lee, M., Kwak, H., Lee, S., \& O’Grady, W. (2011). Processing, pragmatics, and scope in Korean and English. In H. Sohn, H. Cook, W. O’Grady, L. Serafim \& S. Cheon (Eds.), Proceedings of the 19th Japanese-Korean linguistics conference (pp. 297-311).

Stanford, CA: Center for the Study of Language and Information.

Lidz, J., \& Musolino, J. (2002). Children's command of quantification. Cognition, 84, 113154.

Marinis, T. (2010). Using on-line processing methods in language acquisition research. In E. Blom, \& S. Unsworth (Eds.), Experimental methods in language acquisition research (pp. 139-162). Amsterdam: John Benjamins. 
Musolino, J., \& Gualmini, A. (2011). Parsing, grammar and the raising of children at LF. In E. A. Gibson, \& N. J. Pearlmutter (Eds.), The processing and acquisition of reference (pp. 109-132). Cambridge, MA: MIT Press.

Musolino, J., \& Lidz, J.,. (2003). The scope of isomorphisim: Turning adults into children. Language Acquisition, 11, 277-291.

Phillips, C. (1996). Order and structure Unpublished PhD dissertation, MIT.

Pinker, S. (1999). Words and rules. New York: Harper Perennial.

Reinhart, T. (2006). Scope shift with numeral indefinites - syntax or processing? In S. Vogeleer, \& L. Tasmowski (Eds.), Non-definiteness and plurality (pp. 291-311). Amsterdam: John Benjamins.

Schwartz, B. D., \& Sprouse, R. (1994). Word order and nominative case in nonnative language acquisition: A longitudinal study of (L1 Turkish) German interlanguage. In T. Hoekstra, \& B. D. Schwartz (Eds.), Language acquisition studies in generative grammar (pp. 317-368). Amsterdam: John Benjamins.

Sekerina, I. A., Fernández, E. M., \& Clahsen, H. (2008). Developmental psycholinguistics :On-line methods in children's language processing. Amsterdam: John Benjamins.

Snedeker, J. (2009). Children's sentence processing. In E. Bavin (Ed.), The handbook of child language (pp. 331-338). Cambridge: Cambridge University Press.

Szabolcsi, A. (2002). Hungarian disjunction and positive polarity. In I. Kenesei, \& P. Siptár (Eds.), Approaches to hungarian (pp. 217-241). Budapest: Akadémiai Kiadó. 
Trueswell, J. C., Sekerina, I. A., Hill, N., \& Logrip, M. (1999). The kindergarten path effect: Studying on-line sentence processing in young children. Cognition, 73, 89- 134.

Unsworth, S., Gualmini, A., \& Helder, C. (2008). Children's interpretation of indefinites in sentences containing negation: A re-assessment of the cross-linguistic picture. Language Acquisition, 15, 315-328. 